\title{
ESPOLIOS Y VACANTES EN EL SIGLO XVIII: EL CASO PARTICULAR DE UN ARZOBISPO DE SEVILLA
}

\author{
POR \\ CARLOS L. LADERO FERNÁNDEZ ${ }^{1}$ \\ Universidad de Sevilla
}

\section{RESUMEN}

El presente trabajo aborda la gestión de los de espolios y vacantes de eclesiásticos por la corona española desde el Concordato de 1753 y a través del caso concreto del arzobispo sevillano Francisco Solís. Fallecido en el último tercio del siglo XVIII, su patrimonio fue el primero en someterse al control del Estado en la archidiócesis de Sevilla constituyendo uno de los pocos ejemplos estudiados sobre el funcionamiento de las nuevas instituciones responsables de la regalía.

PALABRAS CLAVE: espolios; vacantes; impuestos; siglo XVIII; regalías; arzobispos; Francisco Solís; Sevilla.

\section{SPOLIA AND VACANTS IN XVIII CENTURY: THE PECULIAR CASE OF AN ARCHBISHOP OF SEVILLE}

\begin{abstract}
This essay deals with the management of and ecclesiastic vacant by the Spanish Crown since the treaty with the Holy See and the particular case of the sevillian archbishop Francisco Solís. He passed away in the last third of the XVIII century and his patrimony was the first one which was subject to the Spanish state' control in Seville diocese, becoming one of the few studied examples about the functioning of the new institution responsible for this privilege.
\end{abstract}

KEY WORDS: Spolium; vacant; taxes; 18th century; privileges; archbishops; Francisco Solis; Seville.

Cómo CITAR ESTE ARTículo / CITATION: Ladero Fernández, C. L. 2017. «Espolios y vacantes en el siglo XVIII: El caso particular de un arzobispo de Sevilla». Hispania Sacra 69, 139: 247-261 doi: 10.3989/hs.2017.017

Recibido/Received 20-09-2014

Aceptado/Accepted 23-10-2014

\section{INTRODUCCIÓN Y OBJETIVOS}

Llámense espolios los bienes que arzobispos y obispos dejan al tiempo de su muerte, habiéndolos adquiridos de las rentas de la mitra; y se dicen vacantes las rentas de la mitra que correspondan al tiempo que media desde el fallecimiento del prelado hasta el día de la preconización del sucesor en Roma. ${ }^{2}$

Con estas palabras, el jurista Joaquín Escriche definía en el siglo XIX una regalía muy anhelada por la Corona y,

${ }^{1}$ claderof@gmail.com / ORCID iD: http://orcid.org/0000-0002 $-3198-8440$

2 Suplemento al Diccionario... 1847: 735. en cambio, escasamente estudiada por los historiadores. Con toda seguridad, no por falta de interés. La cuestión de los espolios y vacantes se revela como fuente privilegiada para conocer la realidad concreta de una diócesis así como el desarrollo de parte de las competencias eclesiásticas asumidas por el Estado tras el Concordato de $1753 .^{3}$ Sin embargo, la dispersión y falta de accesibilidad de las fuentes hacen problemática la investigación provocando, a menudo, que el historiador se circunscriba a sólo una parte del proceso de espolio y vacante. De esta manera, mientras historiadores del arte como Gil-Bermejo o Vigo Trasancos han trabajado con detalle los inventarios de bienes que se

\footnotetext{
3 Cortés Peña 1989.
} 
ofrecen, otros han abordado el tema desde el campo del Derecho, caso de Alberto de la Hera o Campos Harriet. ${ }^{4}$ Para la Historia, Barrio Gozalo, Zunzunegui Aranburu u Olivares Terol también han analizado esta documentación, aunque los mayores esfuerzos realizados hasta el momento corresponden a Pablo Antón Solé y Mercedes Calvo Cruz. ${ }^{5}$ Al primero, antiguo canónigo archivero de la catedral de Cádiz, corresponde el estudio del espolio y la vacante del obispo dieciochesco Tomás del Valle. La segunda, en una obra relativamente reciente, repasa la trayectoria de la Subcolecturía de Canarias durante el siglo que permaneció activa: 1753-1851.

Frente a estos planteamientos, proponemos un estudio integral de un proceso de espolio y vacante. En concreto, el que produjo el pontificado del arzobispo Francisco Solís, fallecido en Roma en 1775 y primer titular afectado en la sede de Sevilla tras la instauración de la Colecturía General.

\section{FUENTES Y MÉTODO}

En este trabajo se han empleado fuentes de diversos centros de investigación. En orden prioritario, debemos destacar el Archivo General del Arzobispado de Sevilla de donde procede la mayor parte de la información analizada. Debido a la falta de localización de los fondos de la Colecturía General, el archivo diocesano se convierte en pilar fundamental de este tipo de estudios. ${ }^{6}$ En el AGAS, la documentación de espolios y vacantes forma una serie independiente que se reparte por las secciones de Administración y Justicia del fondo Arzobispal.

En la sección de Administración encontramos el grueso de una información (libros de rentas por maravedíes, ${ }^{7}$ de rentas por especie, ${ }^{8}$ de caudales por ventas, ${ }^{9}$ de nóminas, ${ }^{10}$ testimonios sobre remates de rentas $^{11} \mathrm{y}$ otros libramientos) ${ }^{12}$ que ayuda a reconocer la planificación tributaria del arzobispado y, por ende, los distintos ámbitos jurisdiccionales, gracias a la casuística que se plantea en la distribución impositiva. Además, permiten valorar otros aspectos como el clientelaje en el arrendamiento de los

4 Gil-Bermejo 1970 y Vigo Trasancos 1993. Además de los anteriores: Amores Martínez 2000; Yzquierdo Perrín 2006-2007; Febres 2009; De la Hera 1963 y Campos Harriet 1995.

5 Barrio Gozalo 1982; Zunzunegui Aramburu 1965; Olivares Terol 2001 y Antón Solé 1985. Anteriormente, resaltó la importancia de este tipo de fuente histórica en otro trabajo: Antón Solé 1974 y Calvo Cruz 2000.

6 La documentación de la Colecturía General debió ser asumida por el Archivo Histórico Nacional. No obstante, tras seguir las indicaciones de los facultativos de revisar los legajos de Patronato de la extensa sección de Consejos, no obtuvimos resultados. De la falta de instrumentos de descripción ya se hizo eco Antón Solé en los años setenta quien destacó varios cientos de legajos de la sección de Cruzada donde tampoco tuvimos mejor suerte para el espolio y la vacante de Francisco Solís.

7 Archivo General del Arzobispado de Sevilla [AGAS], Administración, Espolios y Vacantes, legajos no 831, 835, 837, 838, 839, 842, 843, 844, 845. 846.

8 AGAS, Administración, Espolios y Vacantes, legajos no 834, 836,

\footnotetext{
9 Ibídem, legajo no 827.

10 Ibídem, legajo no 829 .

11 Ibídem, legajo $n=841$.

12 Ibídem, legajos no 831, 840.
}

tributos o la riqueza para este momento concreto de las diferentes vicarías en que se organizaba el territorio.

En la sección de Justicia, encontramos varios libros de litigios, ${ }^{13}$ de valores de granos $^{14}$ y el libro de caudales ${ }^{15}$ obtenidos por la liquidación de bienes del prelado que resulta de particular interés para adentrarnos en su forma de vida, aunque el documento generado por la almoneda no sea equiparable al inventario que produjo la Embajada de España en Roma para repatriar los efectos de Francisco Solís tras su fallecimiento. Precisamente, la muerte de Solís en la corte pontificia, donde se encontraba tras participar en el cónclave de elección de Pío VI, complicó la labor de la Colecturía, que hubo de duplicar e incluso triplicar esfuerzos para ajustar la fortuna del cardenal por aquellas ciudades por las que pasó, y de los historiadores por la dispersión documental. Por otra parte, a estos problemas se añaden otros propios del Antiguo Régimen como la mezcla de conceptos que, por ejemplo, hace que en diferentes ocasiones se confundan los ramos de espolio y vacante. ${ }^{16}$

Para nuestro caso de estudio contamos con una veintena de cajas que se fechan desde la muerte del prelado hasta comienzos del siglo XIX cuando se cierra el último adeudo del espolio siendo más abundante la información de este procedimiento que la generada por la vacante a pesar de ocupar un espacio temporal mayor (426 días frente a 79). En total, unos treinta años de información discontinua que ofrecen una imagen fija de la archidiócesis, fundamentalmente económica y asistencial a través de sus rentas y el destino del patrimonio liquidado, y la realidad de un procedimiento novedoso orquestado desde Madrid con no pocas dificultades.

A éstas, hemos sumado información de otras secciones del AGAS, como Secretaría o Liturgia, y otras entidades como el Archivo del Ministerio de Asuntos Exteriores de Madrid, donde localizamos el citado inventario de bienes remitido así como diferentes oficios e instancias cursados por la Embajada, o el Archivo General de Simancas donde se reserva parte de la documentación originada por la presencia del arzobispo en Roma. El Archivo Municipal de Sevilla y el Archivo Histórico Provincial de Sevilla añaden algunos datos útiles para la reconstrucción del perfil del mitrado. Entre ellos, su última voluntad expresada en un testamento inédito de 1766.

El tema lo desarrollaremos a partir de los tres momentos que experimentaron todos los procesos de espolio y vacante: la colectación y liquidación del patrimonio del prelado, la administración del producto resultante y la distribución posterior. Como exigía el espíritu evangélico, toda riqueza eclesiástica que no tuviese como destino la preservación del culto y sus ministros debía retornar a la sociedad en sus miembros más necesitados y éste fue teóricamente el compromiso contraído por el Estado. No obstante, antes de contemplar cómo se produjo la gestión de la regalía,

13 AGAS, Justicia, Espolios y Vacantes, legajos no 1.901, 2.969, $2.974,2.977,3.086$.

14 Ibídem, legajo no 3.041.

15 Ibídem, legajo no 2.973 .

16 Mercedes Calvo insiste en la ineficacia en cuanto a la transmisión de la información contable. En el caso de Canarias, las entradas y salidas se asentaron en los libros de forma cronológica sin distinguir el ramo. Calvo Cruz 2000: 221 y 456. 
dedicaremos algunas líneas a tratar el concepto de espolio y vacante, su evolución histórica y los hitos vitales de Francisco Solís, protagonista del proceso que vamos a trabajar.

\section{EL DERECHO DE ESPOLIO Y LOS PROTAGONISTAS DEL CASO SEVILLANO}

Las primeras líneas de este trabajo las encabeza una definición de los espolios y vacantes del jurista decimonónico Joaquín Escriche. No en vano, el siglo XIX prestó gran interés a la regulación de las instituciones canónicas fabricando numerosas compilaciones que hoy aparecen firmadas por nombres clásicos como Gómez Salazar, ${ }^{17}$ Pedro Benito Golmayo ${ }^{18}$ o Alonso Perujo y Pérez Angulo. ${ }^{19}$ Sin embargo, el derecho de espolio ya hizo correr ríos de tinta en siglos anteriores. Antón Solé lo vincula al derecho de guardia creado por los reyes visigodos para evitar los abusos de la Iglesia y, desde su inclusión en las Partidas, no ha dejado de perfilarse en el intento por la Corona de preservar un derecho que creía inherente y que comenzó a perder de manera accidental cuando la Cámara Apostólica lo capitalizó para nutrir sus arcas a partir del siglo XIV. ${ }^{20}$ Paulo III (15341549) lo sancionó como derecho privativo del papado. ${ }^{21}$ Pío IV (1559-1565) dictaminó que todos los bienes del estamento pertenecían a Roma, muy especialmente aquellos obtenidos de manera ilícita o de quienes morían fuera de sus sedes, salvando únicamente las propiedades de los cardenales y demás miembros de la Curia. ${ }^{22}$ El dominico Pío V (1566-1572), por su parte, confirmó las normas de sus predecesores no sin antes excluir

...aquellos paramentos eclesiásticos, vasos, libros de Iglesia, graduales, misales, y otras cosas sacras y también oro y plata y cualesquiera otros bienes que por uso de los obispos y el culto divino y también en las casas privadas de estos y de los capellanes o de los destinados durante un tiempo a oratorios que también estén bajo la facultad testamentaria. ${ }^{23}$

Es decir, comenzaron a reservarse los "pontificales", concebidos como la dote proporcionada por el obispo a su iglesia en virtud del matrimonio místico que les unía desde el momento de la consagración episcopal, aunque hasta la resolución de 15 de mayo de 1784 no se reguló del todo este aspecto. ${ }^{24}$ Con posterioridad, Gregorio XIII (1572-1585) y Gregorio XV (1621-1623) también precisaron el derecho de espolios sin añadir nada relevante.

Durante esta evolución, la Corona no perdió la oportunidad de pleitear el derecho con Roma aumentando

17 Gómez Salazar 1877.

18 Benito Golmayo 1878.

19 Alonso Perujo y Pérez Angulo 1886.

20 Paulo II (1464-1471), Constitución XXIX: «Los bienes de los beneficiados eclesiásticos que se deciden sin testamento o se disponen sin facultad testamentaria y aquellos cuales permanecen más allá de esas facultades pertenecen a la casa apostólica». Ferraris y Soler 1788.

21 Calvo Cruz 2000: 78.

22 Pío IV (1559-1565), Constituciones VIII y IX. Ferraris y Soler 1788: 403-404.

23 Pío V (1566-1572), Constitución s/n que comienza "Romanos". Idem.

24 Calvo Cruz 2000: 91. los recursos de forma paralela a la consolidación del poder real. De esta manera, con Felipe IV asistimos a uno de los episodios más representativos de este conflicto diplomático gracias a la acción de fray Domingo Pimentel, obispo de Córdoba, y Juan Chumacero, miembro del Consejo Real. Ambos, en un alarde de erudición, desplegaron toda la artillería regia en un memorial que vio la luz en 1633 y que provocó ciertas concesiones del papa Urbano VIII como, por ejemplo, la regulación de las funciones del nuncio. ${ }^{25} \mathrm{Nada}$, en cambio, se consiguió en materia de espolios y vacantes hasta el Concordato de 1737.

Por este acuerdo, se reguló la figura del subcolector y se aplicó la tercera parte de los frutos de las iglesias vacantes a las fábricas parroquiales necesitadas y a los pobres. No obstante, tras décadas de conflicto, esta resolución no satisfizo a nadie y pronto hubo voces discordantes reclamando un nuevo concordato. Éste llegaría en 1753, gracias a la gestión efectiva del marqués de la Ensenada, el padre Rávago y Manuel Ventura Figueroa con Benedicto XIV que se dignó a conceder no solamente el derecho de espolios y vacantes sino también el derecho de patronato universal, culmen del regalismo hispano moderno, con ciertas reservas. ${ }^{26}$ Este hecho, refiere Barrio Gozalo, puso a disposición del monarca unos 12.000 beneficios bien dotados y hasta 20.000 beneficios cuyas rentas no llegaban a los 500 reales al año. ${ }^{27}$

En materia de espolios y vacantes, el rey pasaba a ser la máxima autoridad responsable de la aplicación de los frutos de estos ramos en usos píos nombrando como representante un colector general que debía ser, eso sí, una dignidad de la Iglesia. En contrapartida, Fernando VI se comprometió a ingresar al erario pontificio 233.333 escudos romanos, de una sola vez, y a respetar los 52 beneficios eclesiásticos que la Santa Sede se reservó en España. ${ }^{28} \mathrm{~A}$ partir de este momento, para afrontar el cometido, surgiría la Colecturía General de Espolios y Vacantes que, con cierta autonomía pero unida a la Comisaría General de la Cruzada, funcionó hasta mitad del siglo XIX. A las primeras ordenanzas de origen real, pronto se les unieron las adiciones de su primer colector Andrés Cerezo y Nieva en 1754 y las instrucciones del colector Manuel Ventura Figueroa en $1771 .{ }^{29}$ Junto a la Colecturía General se creó una Contaduría para censurar las cuentas y expedir los libramientos y la Cámara de Cruzada tendría potestad para resolver los pleitos originados durante el proceso formal de espolio. Desde su creación, fue responsable de recaudar las medias annatas de los beneficios eclesiásticos y con las instrucciones de Ventura Figueroa, Real Resolución de 15 de mayo de 1784 y Real Cédula de 1 de marzo de 1785, se precisaron conceptos algo difusos como la reserva de muebles y alhajas personales para el nuevo prelado que podría tomarlos por su valor en el plazo de cinco años. ${ }^{30}$ Los ornamentos sagrados y las piezas litúrgicas, "los pontificales", pasaban al depósito catedralicio

25 Tejada Ramiro 1859-1863.

26 De la Fuente 1873-1875.

27 Barrio Gozalo 2010.

28 Ídem.

29 Antón Solé 1985: 32.

30 Calvo Cruz 2000: 146. En su estudio sobre el espolio del obispo Gonzalo Arias, Olivares Terol menciona estos bienes como la "supeletilia" o alhajas del servicio de la casa. Olivares Terol 2001: 423. 
y los libros quedarían bajo custodia con la intención de crear una biblioteca pública en la residencia episcopal.

En Sevilla, la nueva institución colectora se estrenó al fallecimiento del arzobispo Francisco Solís. Nacido en Madrid en 1713, este eclesiástico era hijo de José de Solís y Gante, duque de Montellano, y de Josefa Folch de Cardona, marquesa de Castelnovo y Pons. ${ }^{31}$ Criado en el entorno de la Corte gracias al empleo de su padre, que era mayordomo y caballerizo mayor del cardenal infante Luis Jaime, comenzó su carrera como prior de la iglesia de Aracena en $1735 .{ }^{32}$ Dos años después ocuparía el empleo de sumiller de cortina y oratorio del infante Felipe desempeñando un papel protagonista en la recepción de su futura esposa, Luisa Isabel de Francia, a quien acabó sirviendo como sumiller hasta que los sucesivos méritos le granjearon las dignidades de tesorero, deán de Málaga y la coadministración espiritual del arzobispado de Sevilla. ${ }^{33}$ En 1749, como arzobispo titular de Trajanópolis, aterrizó en tierras hispalenses para hacerse cargo de la gestión de la archidiócesis, cuyas rentas disfrutaba el Cardenal Infante desde hacía varios años. ${ }^{34}$ Con éste colaboraría y a éste sucedió cuando dispuso su renuncia al rey Fernando VI en 1754, tras ocupar la sede de Córdoba un breve periodo de tiempo (1752-1755)..$^{35}$ Sin embargo, su venida se hizo esperar. La concesión del cardenalato en abril de $1756^{36}$ y la enfermedad que le sobrevino cuando ya se encontraba cerca de Sevilla provocaron que no pudiera entrar en la ciudad hasta el 19 de septiembre de dicho año. ${ }^{37}$ Desde entonces trabajó desde el arzobispado hispalense en aquello que le demandaron los diocesanos $y$, fundamentalmente, en los negocios que le encargaron desde la Corte.

Entre los primeros, fue sobradamente conocida su generosidad. Francisco Solís combinó el ejercicio de la misericordia con el dispendio típico de alguien de su ascendencia y dignidad. Rehabilitó numerosos templos afectados por el terremoto de 1755, levantó desde las ruinas varias iglesias incendiadas y patrocinó la construcción de un colegio jesuita de la misma manera que facultó a su limosnero para que repartiese más de 25.000 reales al mes o al panadero para cubrir las necesidades más perentorias de religiosos y seglares. Esta política del prelado le llevó a pensionar la mitra hasta en tres ocasiones poniendo en entredicho su relación con el cabildo catedral que administraba sus rentas. ${ }^{38}$ Por lo demás, no fue un

31 Existen distintas versiones acerca de su nacimiento. Los testigos del proceso consistorial en 1749 afirman que nació en Salamanca en torno a 1704-1705, lugar y fecha que recoge Vidal Guitarte en su episcopologio. Archivo Secreto Vaticano [ASV], Arch. Concist., Processus Consist., volumen 137, ff. 493-498 (Guitarte Izquierdo 1992: 67). Sin embargo, la mayoría de las fuentes consultadas coinciden en situar el nacimiento del prelado en Madrid en 1713: ASV, Arch. Concist., Acta Camerarii, volumen 38, f. 121; Álvarez Baena 1790; Castellanos de Losada (ed.) 1867; Ballesteros Robles 1912.

32 AGAS, Gobierno, Asuntos Despachados, legajo 24.

33 Ibídem, legajo 21; Alonso Morgado 1906: 661.

34 AGAS, Gobierno, Asuntos Despachados, legajo 21.

35 Gómez Bravo 1778, tomo II: 804. Las bulas de provisión fueron firmadas el 17 de noviembre de 1755 y por ellas se pagaron 13.503 ducados de oro y un julio. Ritzler y Sefrin 1958.

${ }^{36}$ Archivo Histórico Nacional [AHN], Estado, legajo 3.909, exp. 8.

37 Archivo Catedral de Sevilla [ACS], Secretaría, Autos Capitulares, libro 123, ff. 346-347.

38 Martín Riego 2002b: 422-426. eclesiástico innovador dedicándose a poner en práctica aquellas consignas que se daban desde Madrid: evitar el absentismo del clero y la venalidad de cargos, considerar sus rentas de cara a una futura reforma beneficial, procurar la formación a través de las conferencias morales, lograr la uniformidad estética del estamento, erradicar cantos populares no aprobados u observar la moralidad general, particularmente, en las manifestaciones religiosas. ${ }^{39}$ Por otra parte, entre los servicios prestados a la Corona, no podemos dejar de señalar la asistencia a los cónclaves por la muerte de Clemente XIII y Clemente XIV. En concreto, el primero fue de especial relevancia pues, como señala Belmonte Más, era uno de los dos representantes españoles encargados de arrancar al nuevo pontífice la promesa de la disolución de la Compañía de Jesús, expulsada de España tres años antes. ${ }^{40}$ Su disposición a las empresas regalistas lo revistió de honores: en 1765 le fue concedido el hábito de San Genaro con motivo del matrimonio del príncipe Carlos con María Luisa de Parma, ${ }^{41}$ el hábito de la Real Orden de Carlos III le Ilegaría en $1771^{42}$ y, sólo un año después, la Universidad de Sevilla le honró con el doctorado en Teología en agradecimiento por su participación en el traslado de la institución a la antigua casa profesa de los jesuitas. ${ }^{43}$

Precisamente, en acto de servicio a la Corona fallecería en Roma el 21 de marzo de 1775 cuando contaba con 62 años de edad. ${ }^{44}$ Allí se encontraba tras haberse elevado al solio pontificio al cardenal Braschi y en la corte pontificia recibió sepultura con gran boato en la basílica de los Santos Doce Apóstoles de la que era titular. Previamente, el cuerpo fue preparado y expuesto en el Palacio de España donde se alojaba y recibió los honores de una misa de réquiem cantada por el cardenal camarlengo Calini y que tuvo por asistente al propio papa Pío VI. ${ }^{45}$ En aquellos días, comenzarían las gestiones de la embajada que, comandada por el conde de Floridablanca, rápidamente hizo las providencias oportunas para facilitar la labor de la Colecturía General de Espolios y Vacantes. Entre éstas se encontró la de realizar el inventario de bienes del prelado o la de proporcionar, por ejemplo, los gastos que produjo la muerte: unos 2.000 escudos romanos (40.000 reales aprox. $)^{46}$ que se invirtieron en los cuidados médicos previos, la autopsia, los preparativos de la ceremonia exequial y el funeral siendo la inversión en cera uno de los gastos más importantes (cerca de 10.000 reales). ${ }^{47}$

\footnotetext{
39 Ladero Fernández 2010.

40 Belmonte Mas 2000: 72.

41 AHN, Estado, legajo 2.510, exp. 5.

42 Ibídem, libro 1.042. El Escorial, 23 de octubre de 1771.

43 Archivo Histórico de la Universidad de Sevilla [AHUS], Libro de Claustros, no 944, pp. 160-161.
}

44 ASV, Arch. Concist., Acta Camerarii, volumen 38, f. 121. El dato también aparece recogido en ACS, Secretaría, Entrada de Prebendados, legajo 07437. En cambio, Alonso Morgado señala que la defunción se produjo el día 22, información que repiten otros autores posteriores. Alonso Morgado 1907: 669; Ros Carballar 1986: 221; Martín Riego 1992: 526.

45 Molí Frigola 1990: 69.

46 Las conversiones en reales de los escudos romanos en éste y otros casos posteriores se han realizado a partir de la equivalencia propuesta por Antonio Marién: 1 escudo $=20,28$ reales (Marién y Arróspide 1789: 192).

47 En estos sepelios era común el elevado gasto en cera. Una muestra la encontramos en las exequias del obispo canario Bernardo de Vicuña que, estudiadas por Pedro Quintana, invirtieron en dicho concepto el 18,5\% del total (Quintana Andrés 2006: 207). 
La muerte se proclamaría en la sede hispalense el 12 de abril, Miércoles Santo, tras una reunión extraordinaria del cabildo catedral que dispuso la celebración de una vigilia y funeral y dio lectura al testamento del eclesiástico. El único documento que conocemos de esta tipología es el firmado por el arzobispo Solís el 18 de octubre de 1766, probablemente, presionado por los capitulares hispalenses al producirse la primera moratoria de sus deudas como puede deducirse de su lectura. ${ }^{48}$ En primer lugar, tras el protocolo testamentario de invocación, intitulación, declaración de buena salud, profesión de fe y exposición de espontaneidad, el prelado dispone que se le entierre lo más próximo al sagrario de la catedral. Luego, señala que se repartiesen los veinte reales acostumbrados a la causa santa de Jerusalén y que se le dijeran un número de misas que no determina. Posteriormente, realiza una serie de advertencias sobre su patrimonio: la existencia de dos inventarios ejecutados al momento de tomar posesión de las mitras de Córdoba y Sevilla donde se recogen los 120.000 reales que le dejó su padre al fallecer y la compra de la finca de la Fuensanta o San Cristóbal en el término de Palmete. Ésta la legaría al cabildo catedral como heredero universal debiendo liquidar con sus rentas las deudas contraídas por el eclesiástico y mantener a su sobrina Josefa, monja profesa del convento sevillano del Espíritu Santo. Además, si algo sobrase, era voluntad del arzobispo que se creara un hospicio de sacerdotes que atendieran a los pobres y enfermos del Hospital del Amor de Dios o, en su caso, una nueva sillería para el coro de la catedral.

Realizadas las honras fúnebres entre el 18 y el 19 de abril, los actos en homenaje al arzobispo no finalizaron. A fines de octubre de 1776, regresaba a Sevilla el corazón del eclesiástico en un pomo de cristal de manos de su familiar Julio Ponce que también portaba un busto de mármol del fallecido ejecutado por el italiano Juan Adán. La pieza, valorada en 450 escudos romanos pagados contra el espolio, ${ }^{49}$ se depositó en un nicho abierto ex profeso en el coro del Monasterio capuchino de Santa Rosalía al que tanto favoreció en vida Francisco Solís. Por tal ocasión, se celebraron unas primeras honras el día de la recepción del relicario y una ceremonia oficial a la que no faltó su sucesor, el arzobispo Delgado Venegas. ${ }^{50}$

Había pasado más de un año y medio desde la defunción del cardenal y la Sede había dejado de estar vacante. Aún faltaba mucho por liquidar y distribuir del espolio y la vacante del arzobispo Solís, sin embargo, también es cierto que mucho se había hecho.

La Subcolecturía de Sevilla comenzó a funcionar al poco de recibirse la noticia del fallecimiento. Al frente se puso a Ignacio Ceballos, canónigo dignidad de arcediano de Niebla, ${ }^{51}$ con funciones similares a las del colector general aunque las ejercía con dependencia del mismo. ${ }^{52}$ Entre otros, en su equipo figuraron el fiscal Sebastián Herrero, el provisor Miguel Carrillo, el juez de Iglesia Francisco Larrumbe, el juez

48 Archivo Histórico Provincial de Sevilla [AHPSe], Protocolos Notariales, Oficio no 19, legajo 13.149, f. 1.606.

49 Archivo del Ministerio de Asuntos Exteriores [AMAAEE], Santa Sede, legajo 440, exp. 7.

50 ACS, Liturgia, Misceláneas, libro no 86, ff. 142-143.

51 Rubio Merino 1987.

52 Calvo Cruz 2000: 136. de testamentos Pedro de Céspedes, el notario Romualdo de Andrade, Martín Alberto Alvarado de Carvajal que cumplió con las funciones de secretario, el contador Francisco Antonio Domezain, que presenciaba los actos de formalización de inventarios, formalizaba diligencias, elaboraba la cuenta y razón de los caudales dando cuenta de ello a la Contaduría principal, ${ }^{53}$ y los tesoreros Jerónimo del Río Soto y Gaspar de Torrejón. ${ }^{54}$ El primero como depositario del espolio y el segundo como depositario interino debieron encargarse de cobrar y dar recibos llevando un libro de caja en el que los asentaba y que les permitía confrontarlos con las cartas de pago anotadas en el libro del contador..$^{55}$

Una de las primeras noticias que poseemos de su actividad corresponden a dos registros del cabildo donde se toma nota de una doble petición de Ceballos: la relación de bienes del arzobispo y el estado en el que se encontraba el préstamo de 600 pesos realizado por la institución para el viaje a Roma. ${ }^{56}$ Previamente, el 20 de abril de 1775, comenzaba la recaudación del espolio tras inaugurarse la almoneda de bienes del prelado. ${ }^{57} \mathrm{Al}$ menos durante doce años ${ }^{58}$ se produjeron ingresos por diversos medios: un camino largo que unido a la precipitación e inexperiencia de la flamante Colecturía, las interferencias entre las diferentes esferas de la administración y las resistencias del derecho consuetudinario trajeron consecuencias al curso del espolio y la vacante. En primer lugar, estas circunstancias restaron claridad al proceso que, antes de finalizar la fase de recaudación y administración, comenzó a realizar libramientos. Esta situación debió privar al Estado de conocer la auténtica magnitud de la regalía que administraba aunque, como ya decimos, era consciente de ello. Según Calvo Cruz, hasta el mandato del colector Pedro Joaquín de Murcia que comenzó en 1783 no se exigieron estados contables. ${ }^{59}$ En segundo lugar, la dimensión temporal y la escasa organización también tuvo su reflejo en la documentación: no sólo se comenzaron a mezclar los conceptos del espolio y la vacante sino que además a partir del fallecimiento del arzobispo Delgado, seis años después, empezaron a yuxtaponerse las partidas de ambos espolios. Por otra parte, aunque incuantificable, debemos tener presente el fraude patente, sin ir más lejos, en numerosos deudores que traspasaron la frontera del siglo XIX sin haber reintegrado su falta y en la propia rendición de las cuentas. ${ }^{60}$ En todo caso, vamos a intentar descender a los detalles del proceso con toda la claridad que nos ha permitido la fuente histórica.

\section{PRIMERAS PROVIDENCIAS: LA RECAUDACIÓN}

Cuando se producía el traslado o fallecimiento de un obispo, el subcolector ordenaba la ocupación de las casas episcopales para evitar saqueos y requería el cobro de las rentas de la dignidad, separando el producto del espolio y

\footnotetext{
53 Ibídem: 137.

54 AGAS, Administración, Espolios y Vacantes, legajo no 840.

55 Calvo Cruz 2000: 138.

56 ACS, Secretaría, Autos Capitulares, libro no 139, f. 166 vo.-167.

57 AGAS, Justicia, Espolios y Vacantes, legajo no 2.973.

58 El último registro que nos ofrece la documentación corres-
} ponde al pago de un alquiler de la hacienda de la Fuensanta que realizó Antonio Romero el 14 de abril de 1787.

59 Calvo Cruz 2000: 338.

60 Ibídem: 455. 
la vacante. ${ }^{61}$ En el caso de Sevilla, la mitra recibió ingresos por diferentes vías: bienes territoriales, derechos de estola, capellanías, primicias y diezmos. Estos últimos eran los ingresos más importantes. Por ello, antes de apreciar su participación en el espolio y la vacante, es necesario explicar la organización económica de la archidiócesis.

La iglesia de Sevilla en el siglo XVIII se extendía por las actuales provincias de Sevilla, Huelva, parte de la de Cádiz (la actual diócesis de Asidonia-Jerez) y varios pueblos de Málaga. ${ }^{62}$ Como entidad metropolitana, de la iglesia hispalense eran sufragáneas las sedes de Cádiz, Ceuta, Málaga y "Canaria" que unía a las actuales diócesis de Las Palmas y Tenerife. De manera interna, el territorio se dividió en 41 (incluida la de Sevilla que no compartía la condición de foránea) ó 47 vicarias (48 si tenemos presente que con Carlos III se crea la de Nuevas Poblaciones) según fuera el propósito principal la recaudación de rentas o el control pastoral. ${ }^{63}$ Esta variedad responde a una lógica: aquellos territorios que eran de jurisdicción especial (patronato laico, señorío episcopal, abadengos, propiedad capitular, maestrazgo) contribuían según concordia y, generalmente, lo hacían de manera reducida porque entre sus atribuciones se encontraba la de mantener al clero de sus territorios. Por ello, a efectos de tributación del diezmo, podemos considerar una amplia casuística que alteraba la regla general que determinaba que un tercio del todo el diezmo de la archidiócesis se debía destinar a la mesa arzobispal y capitular. ${ }^{64}$ Por ejemplo, en los señoríos episcopales, el arzobispo tenía plena potestad en localidades como Brenes, Villaverde, Umbrete, Cantillana, Zalamea, El Buitrón, El Villar o Ríotinto. No obstante, mientras de las tres primeras recibió todo el diezmo, en el resto gozó únicamente de dos tercios para favorecer a las fábricas de sus parroquias y en Cantillana sólo la mitad tras ceder el otro $50 \%$ al cabildo catedral.

La materia decimal puede clasificarse según diferentes criterios. En este estudio hemos optado por la división del producto entre prediales y personales introduciendo el epígrafe de diezmos menudos para aquellos frutos que se diezmaban en pequeñas cantidades sin especificar tipología. ${ }^{65}$ Esta categoría de diezmos menudos procede de otra clasificación que distingue entre estos y los diezmos mayores que se recolectaban en grandes cantidades como el grano. El motivo de mezclar dos esquemas divisorios no es otro que el de obtener un mayor aprovechamiento de la información: el primero destaca por su nivel de detalle mientras el segundo considera los menudos que tan importantes fueron en la administración hispalense. A efectos documentales, el binomio que se considera son las rentas cobradas en especie y las rentas cobradas en maravedíes. Entre las primeras, figuran el trigo y la cebada

61 Novísima Recopilación... 1805.

62 Martín Riego 2002a: 246.

63 Martín Riego 1990: 20; Ladero Fernández 2011: 175-177.

64 Es necesario precisar que el arzobispo sólo participaba de un $45 \%$ de este tercio cediendo el resto al cabildo en agradecimiento por administrar las rentas. Los otros dos tercios en que se dividía el producto decimal correspondía a los beneficiados y a las tercias reales que rediezmaban a favor de las fábricas de las parroquias.

65 Según la documentación arzobispal, el concepto "menudos" integraría castañas, almendras, nueces, azafrán, camuesas, peros, matalahúga, mostaza, ajonjolí, higos verdes y secos. Martín Riego 1990: 78. no habiendo constancia que se diezmara centeno o avena. ${ }^{66}$ En el segundo grupo se encajarían todas aquellas rentas cobradas en metálico. En rentas prediales aceptamos el líquido obtenido por los cochinos, los cabritos con sus derivados, los conejos, los pollos, pavos y aves, la miel y la cera, huertas, ${ }^{67}$ el trigo, la cebada, las semillas, la uva, el vino y las pasas, el aceite y las aceitunas, ${ }^{68}$ las bellotas, las tejas y ladrillos, la madera, el maíz, la escaña, ${ }^{69}$ las lentejas, el panizo $^{70}$ y la sahína ${ }^{71}$ además de la seda, ${ }^{72}$ los pinos, los higos, los peros y las nueces, los eriazos, el "verde sin huertas" y los menudos. Como rentas personales entendemos la aportada por los potros, becerros, mulas, corderos con sus derivados, aquellos diezmos cobrados en moneda sin especificar tipología así como sus rediezmos, el montante procedente de la casa mayor diezmera o escusada de cada parroquia, ${ }^{73}$ los maravedíes procedentes del ganados, las fieldades, ${ }^{74}$ los extremeños, ${ }^{75}$

66 En ocasiones, Martín Riego incluye el centeno en la categoría de "menudos". Ídem. A su vez, en 1795 Tomás López distingue el cultivo de la avena en Castaño del Robledo en la serranía onubense aunque no señala si participaba en el diezmo (Domínguez Ortiz 1944: 241). También en otras zonas del arzobispado ciertos productos como el arroz que habían gozado de cierta representación en el diezmo bajomedieval no eran considerados en el Setecientos (Herrera García 1980: 275).

67 Nos referimos a coles, lechugas, rábanos, cebollas, berzas, espinacas, zanahorias, pepinos, calabazas, berenjenas, perejil, culantro, hierbabuena, mastuerzo, puerros, ajos, granadas, membrillos, albaricoques, ciruelas, duraznos, manzanas, albérchigas, brevas, peruétanos, melocotones, moras, naranjas, azahar, limones, cidras, toronjas, batatas, alcacer verde, simientes de estas legumbres, cabrahígos, habas verdes, cardos (menos el alcaucil que se incluyó entre los "menudos", las moreras (salvo en Écija donde constituían renta propia), bayón, arrayán, esparto, retama, palma y bellota).

68 En La Rioja, incluso se diezmaron sus huesos (Ibáñez Rodríguez 1994).

69 Especie de trigo primitivo derivado de la escaña silvestre. Hoy día su cultivo se restringe a ciertas montañas de Europa.

70 Planta de la familia de las gramíneas procedente de Oriente y parecida al maíz.

71 La sahína o el sorgo es una planta de la familia de las gramíneas con cañas de dos a tres metros de altura procedente de la India. Sus granos sirven para hacer pan y de alimento a las aves. Sus tallos, de pasto para el ganado.

72 Con frecuencia, productos de la hilaza se diezmaban con otros como ocurría con el lino o el cáñamo que se mezclaban con las lentejas.

73 El escusado fue una contribución sobre el diezmo que adquirió a perpetuidad la Casa de Austria tomando el nombre del vecino que se eximía de pagar a la Iglesia dicho impuesto haciéndolo directamente con la Real Hacienda. Regularmente, el Estado se apropiaba de la mayor contribución de cada parroquia. El hecho de que aparezca contabilizado este concepto en los libros de recaudación decimal de la Mitra nos hace pensar que cierta cantidad fuese detraída en algunas localidades. Con frecuencia, además de casa mayor o casa diezmera, adopta el nombre de casa escusada o mortuoria.

74 Son las rentas que administraba directamente la mesa capitular.

75 Se denominaban así a aquellos ganados que eran comprados fuera de la diócesis así como aquel que salía del arzobispado antes de la festividad de San Juan en el mes de junio. Por ejemplo, los ganados riojanos que hacían verano en Andalucía y Extremadura (de ahí el nombre de la renta) debían diezmar en las parroquias donde sus dueños se encontrasen censados con la excepción del pago del "extremo" en aquellas tierras por razón de privilegio. Este hecho proporcionaba unos ingresos considerables a estas diócesis como refiere Miguel Ángel Melón para la iglesia de Coria a pesar del fraude registrado pues algunos ganaderos aseguraban habérseles exigido el diezmo total y no una prorrata en el "extremo" o argumentaban que sus ganados habían pacido en dehesas privilegiadas (Melón Jiménez 1987 y 1998). 
albarraniegos, ${ }^{76}$ arrendamientos, rentas menores, diezmos mixtos $^{77}$ y, por último, las quiebras que se producían por aquellos arrendatarios que desistían en la contratación de un impuesto sin haber concluido el ciclo, bien fuera por fallecimiento o voluntariamente.

Nuestro estudio permite evaluar la riqueza agropecuaria del arzobispado, aunque siempre con la precaución de considerar el fraude, el prorrateo de las cifras o la falta de perspectiva que provoca un análisis económico tan limitado en el tiempo. En la medida de lo posible, para conseguir un mayor rendimiento de la información, hemos distinguido los ingresos a cuenta del espolio (rentas de los primeros 79 días de 1775 así como aquellos adeudos atrasados del pontificado de Francisco Solís) de los recibidos por la vacante (426 días: desde la muerte del arzobispo el 21 de marzo de 1775 hasta la preconización del sucesor el 20 de mayo de 1776). Por otra parte, por razones obvias, emplearemos la división económica contemplada en los libros de subsidio y excusado. Utilizada por Martín Riego en su clásico estudio sobre las rentas de la mesa arzobispal, haremos algunas apostillas para incluir ciertas unidades de renta que habían sido marginadas. ${ }^{78}$

Comenzando por las rentas en especie, en concepto de espolio se recaudaron 7.168 fanegas, 1.234 almudes y 400 cuartillos de grano en todo el arzobispado y durante la vacante estas cifras ascendieron hasta las 53.395 fanegas, 3.946 almudes y 1.042 cuartillos. En total, valorando todo el proceso de espolio y vacante, se superaron con creces las 60.000 fanegas de grano..$^{79}$ El cereal que más aportó a estas cifras fue el trigo: cerca de 55.000 fanegas para todo el periodo. En ello tuvo mucho que ver las vicarías de la campiña, tanto la de Sevilla como la de Cádiz, así como la vega del territorio hispalense que aportaron cerca de la mitad del producto. Esta circunstancia se debe a la sobresaliente participación de las vicarías de Carmona, Écija, Utrera, Arcos y Jerez que superaron las 2.500 fanegas de trigo y alguna de ellas con creces como es el caso de Utrera que contribuyó con 4.278 fanegas, 116 almudes y 23 cuartillos de trigo en el espolio y la vacante. En territorio onubense a estas cifras sólo se acercó la vicaría de Almonaster la Real. En el extremo contrario, las vicarías de las marismas, la sierra y la costa noroeste de Cádiz apenas aportaron el 3\% del trigo en especie. Entre otras, nos referimos a las vicarías de Aznalcázar, Zahara, El Puerto de Santa María o Rota pero también a Cazalla, El Pedroso, El Castillo de las Guardas en la sierra norte de Sevilla, a Cumbres Mayores, Cala o Santa Olalla en la sierra de Huelva o al caso de la vicaría de Moguer en el litoral del condado de Niebla. En ninguna de ellas se rebasaron las 500 fanegas de tributo. La vicaría marismeña de Aznalcázar, la que menos trigo en especie tributó, apenas superó las cien fanegas.

76 Son consideradas como tales las rentas de aquellas personas que no tenían casa, domicilio o vecindad definida debiendo diezmar en aquellas vicarías donde estuvieran cuando el primer remate de las rentas.

77 Categoría creada por nosotros para salvar la problemática de aquellas rentas indivisibles.

78 Generalmente, estas unidades son despoblados, donadíos o territorios de jurisdicción especial. Para incluirlos en una vicaría determinada nos hemos servido de diferentes estudios: Ladero Quesada y González Jiménez 1978 y Candau Chacón 1994

79 AGAS, Administración, Espolios y Vacantes, legajos no 834, 836, 846 .
Hablando de la cebada, las cifras caen vertiginosamente hasta el punto que no se tributa en ciertas comarcas de la archidiócesis. El volumen que se ingresó de este cereal en la mesa arzobispal no alcanzó las 9.000 fanegas por concepto de espolio y vacante, apenas el $13 \%$ de todas las rentas aportadas en especie. De las zonas con representación destaca la vega de Sevilla por el aporte de más de 2.000 fanegas que hizo la vicaría de Cantillana. En contraste con el extraordinario dato facilitado por la campiña sevillana para el trigo, en este caso sólo nos encontramos con una cifra discreta que supera las 1.400 fanegas gracias a la participación de la vicaría de Osuna cuyo extenso territorio no sólo se expandía por la campiña sino que recorría también parte de la sierra sur. La vicaría de Utrera, en esta ocasión, apenas destacó con un centenar de fanegas de cebada. Sin contar aquellas que no ofrecieron nada, la contribución de la vicaría de Arcos fue la más insignificante: 2 fanegas, 16 almudes y 2 cuartillos en un periodo cronológico que superaba el año sin contar con todos aquellos atrasos en los pagos que fueron recogidos en la cuenta del espolio.

Una vez recaudado, el grano se almacenaba en alguna de las setenta cillas que, según Martín Riego, poseía la archidiócesis para después efectuar la venta de una parte. ${ }^{80}$ El historiador refiere que por este concepto se recaudaron 1.326.421 reales en 1775 y 834.389,16 reales en 1776 , una caída del 37\% que parece corroborar las buenas cosechas de 1776 y, por consiguiente, el abaratamiento de los precios. Sin embargo, al no encontrarse prorrateadas las cifras, resulta imposible conocer el numerario que perteneció al espolio y la vacante de Francisco Solís.

De mayor importancia al proceso fueron las rentas cobradas en maravedíes. Nuestros cálculos permiten estimar un capital superior a los 3.500 .000 reales de los cuales unos 635.000 eran fruto del espolio y más de dos millones tenían como origen la vacante. ${ }^{81}$ La diferencia entre ambos datos responde a aquellas partidas que no distinguen el ramo al que pertenecen. Si comparamos el total con la aproximación que, sobre las rentas de maravedíes, ofrece Antón Solé para el espolio y la vacante del obispo gaditano Tomás del Valle la diferencia es abismal: 446.862 reales, apenas el $13 \%$ de la cifra sugerida por nosotros, aunque la ausencia de estudios integrales para otras diócesis le resta valor. ${ }^{82}$

Como hemos podido apreciar en el caso de la tributación en especie, las campiñas de la archidiócesis y la vega de Sevilla fueron los territorios con mayor participación. La campiña sevillana aportó más de un millón de reales, un $30 \%$ del total, mientras la gaditana hizo lo propio con cerca de 600.000 reales. En ello, fue indiscutible el peso de las vicarías de Jerez, Arcos, Écija y Marchena. Todas tributaron por encima de los 200.000 reales mientras Utrera, que destacó entre las rentas recaudadas en especie, se quedó en 163.074 reales. Un dato, en cualquier caso, nada irrelevante frente a la contribución de otras circunscripciones eclesiásticas como la vicaría de Aznalcázar que con 337 reales vuelve a quedar en la base de la jerarquía impositiva si excluimos ciertos territorios que se sujetaron a concordia. Tampoco las vicarías de El Pedroso, Cañete la Real en el límite noroccidental de la

80 Martín Riego 1990: 144.

81 AGAS, Administración, Espolios y Vacantes, legajos no 828, 830, 833, 835, 837, 838, 839, 842, 843, 844, 845.

82 Antón Solé 1985: 129-130. 
actual provincia de Málaga, las onubenses de Santa Olalla y Cala y las gaditanas de Zahara y Villamartín llegaron a los 10.000 reales.

Según el tipo de cultivo, de nuevo, el trigo corona las entradas de metálico en el erario episcopal. Fuente de ingresos prioritaria en casi toda la archidiócesis, sólo en las marismas y la sierra de Cádiz fue desbancada por la venta de semillas y la presencia del olivo, respectivamente. En segundo lugar, los diezmos "menudos" romperían la trilogía mediterránea y a estos le acompañaron en precedencia el aceite con gran beneficio en las campiñas, la vega, la sierra de Cádiz y la sierra sur de Sevilla. Las rentas por vino, sin ser de las primeras, arrojaron importantes caudales en el litoral, el aljarafe y sierra norte de Sevilla mientras el producto por corderos y derivados fue relevante, sobre todo, en la serranía sur de Sevilla y Cádiz. Además de los ingresos por estos productos no hemos de olvidar la participación de la miel y la cera en lugares como el Andévalo onubense. Allí, según el catastro de Ensenada, se repartieron cerca de 40.000 colmenas. $^{83}$

Tras analizar los ingresos por rentas decimales al espolio y la vacante debemos detenernos en otra vía de liquidación: la formación de inventarios. Como ya hemos dicho, la accidental muerte del prelado en Roma determinó el curso de su espolio, principalmente, en lo que refiere a la dispersión de sus bienes muebles repartidos entre varias ciudades. Así, mientras en la corte pontificia la embajada aún continuaba el registro de enseres y alguna que otra venta, ${ }^{84}$ buena parte de los efectos que llegaron a Madrid se liquidaron y pasaron directamente al fondo de bulas (procedentes, sobre todo, de la venta de alhajas) y en Sevilla se abrió una almoneda pública con las pertenencias de las casas del arzobispo. El inventario que debió de realizarse en la capital del arzobispado no lo hemos localizado y el documento generado por la subasta es diferente al registro realizado en Roma como diversos eran sus fines. Este cúmulo de circunstancias no permite que podamos aproximarnos a la riqueza que generó el patrimonio de Francisco Solís, aunque sí analizaremos las distintas fuentes por separado para hacernos una idea y, sobre todo, para reparar en el tren de vida del prelado a través del consumo y destino del gasto.

El inventario romano comenzó a ejecutarse el 21 de marzo de 1775 por orden expresa del Conde de Floridablanca. Bajo la supervisión del notario Felipe Mariotti y del secretario real José Igareda en éste intervinieron diversos peritos de la ciudad como el joyero Miguel Maceli, José Marini, guarnicionero, o el regatero Juan Sabatini que detallaron al margen del documento el justo valor de los bienes. La tasación total y el dinero en efectivo que se recibió estuvieron cerca de los 40.000 escudos, es decir, sobrepasaban los 800.000 reales. ${ }^{85}$ Por su parte, el documento de la almoneda nos revela los bienes que se liquidaron, a qué precio y cuáles fueron sus compradores. ${ }^{86}$

83 Catastro de Ensenada: http://pares.mcu.es/Catastro/. Libro no 560 pp. 844-857 vo.; pp. 858-873 vo. Libro no 561 pp. $729-745$ vo.; pp. 802-819. Libro no 562, pp. 1.258-1.271; pp. 1.296-1312 vo. Libro no 563, pp. 440-447; pp. 897-909 vo.; pp. 1148-1171 vo.

${ }_{84}$ Sin ir más lejos, en Roma se vendió una partida de 15 caballos por unos 32.000 reales. AMAAEE, Santa Sede, legajo 440, exp. 7. El documento no se encuentra paginado.

85 AMAAEE, Santa Sede, legajo 440, exp. 7.

86 AGAS, Justicia, Espolios y Vacantes, legajo no 2.973.
Todo ello aparece encabezado por el nombre de los tesoreros del espolio como responsables de las cuentas y datado en el tiempo y el espacio. En este caso, el líquido obtenido por la venta y otras restituciones superó el millón de reales. Fuera de estas cifras quedarían aquellas deudas contra el espolio que, en el caso de la administración sevillana, se resolvieron por vía ordinaria a lo largo de todo el proceso como luego veremos. A su vez, trataremos los débitos contraídos por el prelado en Roma y que fueron condonados al momento de realizarse el inventario, posiblemente, para favorecer la labor de la Subcolecturía.

Los bienes mejor considerados por los agentes de Roma fueron la plata labrada y las joyas seguidos a distancia por los carruajes y sus equipos. Entre ambas categorías, se encierra más del $80 \%$ del aprecio total del inventario. Una clara muestra de ostentación social donde una de las piezas más valiosas, una cruz de la Orden de Carlos III de brillantes, obtuvo el aprecio de 3.600 ducados, unos 73.000 reales. Mientras, las partidas referidas al menaje, la despensa, la biblioteca o al arte apenas fueron consideradas por falta de representación o por escaso impacto económico. En el caso del menaje, sólo hemos reparado en aquellas piezas que no fueron ejecutadas en materiales ricos como el cobre o el hierro, de ahí que fueran poco estimadas a pesar de alcanzar un volumen nada despreciable. Las circunstancias que explican el bajo porcentaje de la despensa, la biblioteca y el arte son otras. En la primera, posiblemente se reparó en el deterioro de aquellos bienes perecederos y, lejos de anotarlos en el inventario, debieron repartirse entre las familias española e italiana del cardenal. Sólo se anota una partida de 54 rubios de avena que por su localización en el inventario, tras describirse las caballerizas, hacen pensar que fueran alimento para el ganado. Tampoco tienen importancia la biblioteca y el apartado artístico que casi no deberíamos darle esa consideración. Las lecturas que se anotan se limitan a un juego de breviarios que acompañarían al purpurado en sus oraciones cotidianas, aunque sus intereses, como se podrá apreciar más adelante y como describen las crónicas de sus viajes a Roma, iban por otros derroteros. Las obras de arte que se mencionan, tres retratos y un oratorio portátil, tampoco merecerían estar aquí. ${ }^{87}$ Sin embargo, para ser puristas, son las únicas partidas individuales que pueden acercarse a estos grupos pues, de manera colectiva o como deudas pagadas contra el espolio, aparecen piezas a tener en cuenta y que no hemos incorporado por respetar la estructura ofrecida por los peritos a la Colecturía. Nos referimos, por ejemplo, al busto de mármol ya mencionado que Juan Adán realizara del cardenal por 450 escudos, unos 9.000 reales, o al ostensorio que encargó a Juan Bautista Floreti, valorado en unos 52.000 reales, regalo póstumo a la iglesia de Sevilla que hubo de esperar en la reserva de la Subcolecturía como aval hasta saldar las deudas más importantes. ${ }^{88}$

En España, la liquidación obtuvo sus mejores datos en el apartado de dinero en efectivo, la plata labrada y las joyas así como en el menaje. En metálico se anotaron unos 273.788 reales: casi un $25 \%$ del total siendo la mayor parte procedente de rentas de maravedíes pendientes. En

\footnotetext{
87 Álvarez Santaló y García-Baquero 1980.

88 AMAAEE, Santa Sede, legajo 440, exp. 7.
} 
segundo lugar, distintas cruces de órdenes y varias cajas labradas en materiales preciosos que llegaron a Madrid procedentes desde Roma engordaron el caudal del espolio hasta cerca de los 200.000 reales. Por último, la categoría de menaje, donde se registraron varios miles de piezas, aportó algo más de 150.000 quitando protagonismo a los carruajes y sus equipos que, en esta ocasión, apenas se vendieron por unos 58.000 reales. Esta circunstancia parece lógica si ponemos en relación los deseos del prelado por aparentar y la provisionalidad de la vivienda romana que haría innecesaria la compra de más piezas de menaje. No debemos olvidar que Francisco Solís se alojó durante este viaje en el Palacio de España que ya contaría con lo necesario. Estos saldos contrastan con el apartado de biblioteca y arte que, una vez más, se revelan insignificantes frente a otros grupos de bienes: $2.290,17$ reales (un $0,2 \%$ del total) y $16.773,16$ reales, respectivamente. ${ }^{89}$

Para un mejor conocimiento de las opciones de consumo del prelado $y$, en definitiva, de la vida material en el siglo XVIII a través de las diferentes compras que se realizaron, hagamos un breve repaso a los distintos grupos en los que hemos clasificado los bienes de uso personal.

En primer lugar, abordaremos la sección de plata labrada y joyas por su importancia cualitativa y económica tanto en el inventario como en la almoneda. En Roma, se tasaron unas 400 piezas por un valor total que rondó el medio millón de reales gracias en gran medida al menaje realizado en plata donde se combinaron piezas como las terinas, un sortú, varios juegos de platos o trincheros. No faltan las manuelinas para el chocolate tan de moda entre la élite, una cafetera, rara avis que Máximo García sólo encuentra en un $7 \%$ de las dotes castellanas del Setecientos, ${ }^{90}$ y hasta once cajas elaboradas en ricos materiales como la plata, el oro o el carey y que, según un estudio realizado por Pilar Andueza a una familia de la alta nobleza navarra, pudieron servir como tabaqueras o estuches para el rapé. ${ }^{11}$

En el apartado de menaje, los taburetes, las mesas y las sillas tuvieron gran protagonismo en la venta realizada en Sevilla (cerca de 40.000 reales se pagaron por unas 500 piezas), aunque no tanto como los vidrios exentos ya fueran de ventanas, puertas u otro tipo de mobiliario: 1.500 unidades aprox. Algunas por menos de dos reales. Idéntica circunstancia se registró en Roma donde el notario a veces agrupa las piezas por su escaso valor. Todo lo contrario ocurrió con el único biombo de la colección que fue comprado por 5.265 reales por Juan José de Lesaca, quizás intendente del ejército. ${ }^{92}$

Por otra parte, los textiles también tuvieron su significación en los registros. En Roma, el notario distinguió cerca de 600 piezas entre la ropa de uso del cardenal, la ropa blanca y el vestuario litúrgico. La ropa blanca es la más voluminosa y la menos apreciada si descontamos los dos reposteros de

89 AGAS, Justicia, Espolios y Vacantes, legajo ํo 2.973.

90 García Fernández 2008: 141.

91 Andueza Unanua 2009: 281.

92 AGAS, Justicia, Espolios y Vacantes, legajo no 2.973. Antonio Luis López al tratar el origen de la ganadería de la familia Picavea de Lesaca/Montemayor señala que el fundador era hijo de un navarro, Juan José de Lesaca, que era intendente honorario del ejército, del Consejo de Hacienda y contador general de Guerra de la Tesorería Mayor del rey que murió en 1831 (López Martínez 2002: 324). terciopelo carmesí bordados que ascendieron a unos 14.196 reales. Prueba de que todo era susceptible de ser inventariado es la inclusión de una docena de calzoncillos del cardenal que se tasaron en 240 reales. Los vestidos y complementos del cardenal, por su parte, oscilaron entre los 40 escudos en que se estimó uno de "terciopelo rojo encarnado con fondo de oro forrado en felpa de seda" y los tres escudos en que fue valorada una chupa de grana encarnada vieja.

Las ropas sagradas pudieron enajenarse hasta que una resolución del monarca de 1784 lo prohibió y, quizás por ello, encontramos el aprecio que los agentes de la embajada hicieron de los pontificales del eclesiástico. ${ }^{93}$ Uno de ellos, el más caro, en 300 escudos. ${ }^{94}$ En Sevilla, no hay constancia de este tipo de ventas. Incluso, hay noticia de una reunión del cabildo el 30 de agosto de 1776 donde se acuerda solicitar la remisión de las ropas y alhajas del pontifical de Francisco Solís al comisario general de Cruzada. ${ }^{95}$ Según nota de los señores de Fábrica de la catedral de 13 de septiembre del mismo año, estos efectos vendrían a sumarse al oratorio sevillano del cardenal que fue valorado en 91.696,06 reales y quedarían en la reserva de la Subcolecturía hasta que se conociera el signo final del balance, positivo o negativo, del espolio. ${ }^{96}$ Como ya hemos visto, así ocurrió con el ostensorio romano que pensaba regalar el arzobispo y una denuncia de los señores de Fábrica acerca del deterioro que sufrían los enseres por las humedades que soportaba la estancia que los contenía. ${ }^{97}$ Ante esta situación, el Cabildo acordó el cambio de lugar pero no la libre disposición de los objetos, como revela una nueva petición de misales cuatro meses después, ${ }^{98}$ hasta que la Colecturía General facultó el uso a los capitulares en junio de 1777. Aunque para entonces desde Madrid se confiaba en la capacidad del espolio para solventar todos los adeudos, el cabildo catedral apostó por la moderación acordando el uso de los pontificales, pues la falta de uso contribuía a su corrupción, a excepción de las alhajas. ${ }^{99}$ Entre aquello que sí se pudo vender en la almoneda debemos destacar el éxito que obtuvieron las mercadurías (decenas de varas de damasco, terciopelos, holandilla...por las que se recaudaron más de 30.000 reales), los galones o las cortinas ( 13.125 reales por la venta de 87 unidades). ${ }^{100}$

Los carruajes y sus equipos tuvieron gran repercusión en la composición del inventario romano. Con una participación del 19,62\% en el aprecio total, esta categoría funcionó como un verdadero escaparate de las excelencias de la dignidad. Así lo demuestran los diferentes coches que la compusieron $y$, principalmente, uno: la estufa noble que perfectamente tapizada en terciopelo, guarnecida con galones y bordados y decorada con sedas llegó a valorarse en 3.800 escudos romanos, unos 77.000 reales. ${ }^{101}$ Sabemos que el arzobispo Delgado Venegas compraría una de estas carrozas. Sin embargo, al incluirse en una partida mixta, desconocemos cuál de ellas y si el nuevo prelado se acogió al derecho

\footnotetext{
93 Calvo Cruz 2000: 146

94 AMAAEE, Santa Sede, legajo 440, exp. 7.

95 ACS, Secretaría, Autos Capitulares, libro no 139, f. 238 vo.

96 Ibídem, libro no 139, f. 299 vo.

97 Ibídem, libro no 140, f. 20 vo.

98 Ibídem, libro no 140, f. 105.

99 Ibídem, libro no 140, f. 173.

100 AGAS, Justicia, Espolios y Vacantes, legajo nㅇ 2.973.

101 AMAAEE, Santa Sede, legajo 440, exp. 7.
} 
de reserva que ofrecía la Colecturía dentro de los cinco primeros años. La compra se efectuó a los pocos meses de su preconización cuando aún no había hecho entrada en la archidiócesis: 12 de septiembre de 1776.

Las partidas de ganados alcanzaron cifras más discretas. Con escasa relevancia en el registro elaborado en Roma donde sólo se contabilizan 15 caballos, en la subasta de la capital hispalense se consiguieron más de 100.000 reales para el espolio por la venta de varias cabezas de mulas (donde se obtuvo un $97 \%$ del total), venados, jacas y ciertas aves. ${ }^{102}$ Los estudios de Sanz de la Higuera nos ayudan a poner en valor estos datos pues el arzobispo de Burgos, Diego Felipe de Perea, contemporáneo de nuestro eclesiástico, no tenía en su caballeriza más que trece mulas y una pollina. ${ }^{103}$

En circunstancias parecidas encontramos la división de la despensa y los productos agrícolas: prácticamente nada que catalogar en Roma mientras en España el producto recaudado ascendía a 146.820 reales, cerca de un $13 \%$ del capital cosechado en la almoneda, y gracias particularmente a un concepto: las 3.232 fanegas de trigo almacenadas y que generaron 113.020 reales. A éste le siguieron muy de lejos por encima de mil arrobas de paja, varios cientos de fanegas de cebada, algunas libras de café, tabaco y chocolate, una veintena de arrobas de aceite, varios platos de aceitunas, espárragos, algunos kilos de naranjas chinas de la hacienda de la Fuensanta, propia del arzobispo, e incluso el pato que Juan de Matony compró por 60 reales. ${ }^{104}$

Un impacto mínimo sobre el espolio (inferior al 2\%) tuvo la biblioteca del prelado así como aquellas piezas artísticas o decorativas. Vayamos por partes. En una venta de 16.773,16 reales encontramos relojes, pinturas, láminas, relicarios y alguna que otra imagen religiosa. Pinturas y láminas fueron las partidas más numerosas (89), aunque no las más cotizadas pues, en su conjunto, apenas superaron los 6.000 reales: casi la mitad del valor de la colección sevillana del Marqués de Loreto donde, precisamente, según Porres Benavides, acabó el retrato que el italiano Pompeo Batoni hiciera del cardenal en 1769. ${ }^{105} \mathrm{~A}$ la luz de nuestros datos, en un primer momento fue vendido al medio racionero José de la Raya por 1.400 reales. Entre los nombres conocidos figura además el de los ya mencionados Juan Adán, Juan Bautista Floreti o el de Francisco Preciado de la Vega, académico afincado en Roma que realizó para el arzobispo Solís tres retratos de Fernando VI, la reina Bárbara y el papa Benedicto XIV valorados en unos treinta reales/unidad, según el inventario. Un reloj encarnado que perteneció al cardenal fue la pieza que más se cotizó: 1.500 reales. ${ }^{106}$

La aportación de la biblioteca al espolio fue todavía inferior. En principio, constituyó una obligación de la Colecturía General reservar los libros de la dignidad para el aumento o la creación de una biblioteca episcopal, herramienta básica que complementa y, en algunos casos como el de Sevilla, podía llegar a paliar los efectos negativos de no tener seminario diocesano aún a fines del siglo XVIII.

102 AGAS, Justicia, Espolios y Vacantes, legajo no 2.973.

103 Sanz de la Higuera 2002: 209.

104 AGAS, Justicia, Espolios y Vacantes, legajo no 2.973.

105 Álvarez Santaló y García-Baquero 1980: 34; Porres Benavides y Sánchez López 2008.

106 AGAS, Justicia, Espolios y Vacantes, legajo no 2.973.
La institución central, en nombre del Rey, se dedicó incluso a regular las horas de trabajo del bibliotecario que recibiría sus honorarios de los frutos de la mitra:

Reservanse asimismo desde ahora en adelante perpetuamente á favor de las Mitras todas las librerías de los Prelados, que se encontrasen al tiempo de su muerte, para el uso de sus sucesores y familia, y para el aprovechamiento público de sus diocesanos, principalmente de aquellos que se dedican al estudio de la predicación, y demás exercicios del pasto espiritual de las almas(...). ${ }^{107} \mathrm{~A}$ la muerte del Prelado formará el subcolector un índice de libros que dexase, con expresión de sus autores, materia de la obra, y lugar de impresión(...). ${ }^{108}$ En inteligencia de que tengo mandado aplicar á estas librerías públicas los libros que no se hallan destinados, de los expulsos de la Compañía(...). ${ }^{109}$

Por la notoria utilidad que resulta á las Mitras y sus diocesanos, se declara también por necesario en cada diócesi un empleo de bibliotecario, con la obligación de responder de los libros que se le entreguen y asistir en la librería ó la biblioteca tres horas por la mañana y dos por la tarde, todos los días que no sean festivos(...). ${ }^{110}$ Por razón de su trabajo se la han de asignar de los frutos de la Mitra de quatrocientos á ochocientos ducados, según el prudente arbitrio del Prelado(...). ${ }^{111}$ Se me harán presentes estas asignaciones de los bibliotecarios para tenerlas en consideración al tiempo que se cargan las pensiones de la Mitra. ${ }^{112}$

Sin embargo, en la archidiócesis hispalense, la librería episcopal no abrió al público hasta 1792 bajo el pontificado del arzobispo Llanes y Argüelles que fue uno de sus principales mecenas, según demuestran los índices elaborados por el bibliotecario Tomás de Morales para la ocasión. El primero de ellos, Morales lo reserva para aquellas donaciones de prelados anteriores pero ni distingue entre ellos ni menciona expresamente en la portada a Francisco Solís como hace con los arzobispos Luis de Salcedo y Francisco Javier Delgado. ${ }^{113}$ Por tanto, las únicas obras que podemos vincular de manera cierta al prelado que nos ocupa son esa mayoría de sermones, oraciones y novenas anónimas (cerca del 70\%) que recogen su documento de espolio y que, vendidas por $2.290,17$ reales, debieron ser obras repetidas o de menor interés desechadas por la Subcolecturía. La escasa diligencia del mitrado en buscar ubicación a la biblioteca de los jesuitas expulsos de Écija, cuando tan receptivo fue a otras encomiendas regias, permite intuir una escasa preocupación cultural. ${ }^{114}$ Sin embargo, el documento de venta no justifica la falta de un inventario de los subcolectores que detalle lo aportado por Francisco Solís y, en su caso, lo que se reservó para la biblioteca diocesana.

\footnotetext{
107 Novísima Recopilación... 1805: ley XXVIII, título XIII, libro II.

108 Ibídem: ley XXIX, título XIII, libro II.

109 Ibídem: ley XXX, título XIII, libro II.

110 Ibídem: ley XXXI, título XIII, libro II.

111 Ibídem: ley XXIV, título XIII, libro II.

112 Ibídem: ley XXXV, título XIII, libro II.

113 Índice alfabético de los libros de la Dignidad Arzobispal de
} Sevilla que dexó el Excmo. Señor D. Luis de Salcedo: con agregación de los del Emmo. Señor Cardenal Patriarca y Arzobispo Dn. Francisco Xavier Delgado. Tomo 1으. Biblioteca del Arzobispado de Sevilla [BAS], 33/210. Índice alfabético de los libros que agregó el Excmo. Señor Dn. Alonso Marcos de Llanes, Arzobispo de Sevilla, Cavallero Gran Cruz de Carlos III à los de esta Dignidad, comprendidos en 1 으o tomo para formar esta Biblioteca que mandó publicar en 12 de abril de 1792 . Tomo 2ㅇ, BAS, 33/211.

114 AGAS, Gobierno, Asuntos Despachados, legajo no 38. 
En la almoneda, el mayor desembolso al respecto lo hizo el canónigo Vilar que, por 700 reales, adquirió los dos tomos de la "Historia Gótica" del padre Mariana, "El Obispado de Palafox" en 16 volúmenes y los tres tomos que se vendieron sobre la causa de beatificación del mismo eclesiástico. ${ }^{115}$ Son pocos los que superaban la categoría de "menudencias impresas" como califica Álvarez Santaló a todos aquellos escritos que no superaban los diez reales. Aunque para el religioso el libro constituyera un objeto cultural familiar y cotidiano, añade el historiador, los fondos que registraba el estamento solían ser un $50 \%$ menos valioso que los inventariados a profesionales liberales y funcionarios. ${ }^{116}$

Finalmente, no debemos olvidar aquellas partidas que, por descuido o falta de organización de los agentes de la Subcolecturía que posiblemente se sucedieran a lo largo del proceso, aparecen mezcladas y que aportaron al espolio más de 60.000 reales. La presencia de algunas piezas es realmente curiosa como la baraja de cartas, tan criticada dentro del estamento, un exótico guacamayo, un cochecito de juguete y hasta "dos pedazos de piedras encajonadas" que compró José María Divicia junto a unas fundas de taburetes. ${ }^{117}$ Esta afición a las gemas parece que estaba extendida entre el episcopado. Según refiere Antón Solé, el subcolector de Cádiz envió al Gabinete de Historia Natural de Madrid una caja de minerales de azufre y plata procedentes de Rotterdam para el obispo Tomás del Valle por no saber qué hacer con ella. ${ }^{118}$

A lo dicho, hay que sumar el dinero en efectivo y las deudas a favor con las que contó el espolio: unos 300.000 reales entre lo que se obtuvo Sevilla y el saldo que arrojaron las cuentas de Roma tras finiquitar las deudas del prelado. Además de rentas en especie, maravedíes y liquidaciones por inventario, el subcolector Ignacio Ceballos recibió también otros pagos en metálico. A través de las restituciones secretas, diferentes religiosos aportaron unos 20.000 reales al espolio. No fue la única vía de entrada de efectivo: a los 245.397 reales obtenidos por diferentes rentas hay que añadir una liquidación de las minas de Ríotinto (435 reales) y aquellas memorias testamentarias que Pío García Tagle, familiar del prelado y prebendado de la catedral, dejó en su testamento (3.400 reales). ${ }^{119}$

Algunas de estas deudas acabaron en litigio y la institución hubo de personarse en defensa del espolio y la vacante. Muchas, se prolongaron indefinidamente $y$, en algunas, se admitió la rebaja como vía de integración de una parte del capital que creía perdido como así lo admitieron en una nota José Larraya e Ignacio Zalduendo al colector general en $1791 .^{120}$ En ocasiones, se repitieron los protagonistas. Sumadas las cantidades adeudadas en la docena de expedientes localizados los datos que obtenemos alcanzan los 112.479 reales, 157 fanegas y 8 almudes de trigo para el espolio y 909 reales para la vacante. ${ }^{121}$ El débito mayor de los conocidos se les exigió a José y Juan Estrada, vecinos de Algodonales en la sierra de Cádiz: 31.969,8 reales

\footnotetext{
115 AGAS, Justicia, Espolios y Vacantes, legajo no 2.973.

116 Álvarez Santaló 1997.

117 AGAS, Justicia, Espolios y Vacantes, legajo no 2.973.

118 Antón Solé 1985: 127.

119 AGAS, Justicia, Espolios y Vacantes, legajo no 2.973.

120 Ibídem, legajo no 2.977

121 Ibídem, legajos no 1.901, 2.969, 2.974, 2.977, 3.086.
}

por unas rentas por frutos del año $1758 .{ }^{122}$ No conocemos el resultado de esta denuncia que llevaba arrastrándose tres décadas. Sí sabemos, en cambio, que hasta el 6 de noviembre de 1806 no se registró la última resolución conocida en los expedientes de justicia: una deuda de algo más de unos 15.000 reales contraída por Santiago Sabala e Ignacio Laguna, administradores de aceite de El Puerto de Santa María, en $1769 .^{123}$

\section{DE LA ADMINISTRACIÓN DEL ESPOLIO Y LA VACANTE A SUS ÚLTI- MOS LIBRAMIENTOS}

El proceso de administración y distribución del espolio y la vacante corrió paralelo a la recaudación del producto, aunque la documentación que generaron fue sensiblemente menor. A medida que fue entrando el capital en la Subcolecturía, se fueron aprobando pagos por distintos conceptos: acreedores probados, cargas y pensiones que soportaba la mitra, salarios de la Subcolecturía y gastos ocasionados por la vigilia y funeral en Sevilla. ${ }^{124}$ Del mismo modo, comenzaron a realizarse pagos a instituciones religiosas, asistenciales y a particulares necesitados dando fin al principal objetivo de esta política.

Entre 1775 y 1797, la delegación sevillana de espolios y vacantes expidió cerca de cuatro millones de reales para cubrir aquellas deudas contraídas por el arzobispado en tiempos de Francisco Solís y su vacante así como aquellos gastos de funcionamiento de la Subcolecturía. Desde el fallecimiento del prelado hasta 1786 anualmente se firmaron libramientos de distinta cuantía que hicieron oscilar el saldo final de cada ejercicio y sólo en 1789 y 1797 observamos la firma de partidas extraordinarias.

Las libranzas de los años 1776 y 1777 fueron las más copiosas (2.379.814,17 reales aprox.). En estos dos años en que se produjeron las principales recaudaciones del espolio y la vacante también buscaron saldarse aquellos débitos más importantes de la dignidad: censos atrasados, devoluciones de préstamos, gastos funerarios, alcances de iglesias o capillas de la jurisdicción del arzobispo, pensiones sobre la mitra y nóminas de oficiales del arzobispado, de encargados de las fieldades, trojeros, pregoneros de rentas, de los miembros de la Subcolecturía, del maestro y del administrador de la localidad de Umbrete, señorío episcopal.

En 1778, la caída de los libramientos fue del 95\% respecto al año anterior y, a pesar de los altibajos que sufrió la gestión del caudal del espolio y la vacante, las cifras de años posteriores no fueron equiparables. Sin embargo, la alta variación entre cifras no sólo dependió del caudal que entraba en las arcas de la Subcolecturía. La institución responsable juega un papel decisivo por la irregularidad de sus confusas anotaciones que incluso hacen pensar en una errata cuando observamos que en el año 1797, varios años después del último libramiento, se efectuó el pago de más de 400.000 reales por censos atrasados. ${ }^{125}$ Esta realidad se

\footnotetext{
122 Ibídem, legajo nㅇ 2.969.

123 Ibídem, legajo no 2.977.

124 AGAS, Administración, Espolios y Vacantes, legajos 831 y 840.

125 Ibídem, legajo no 831.
} 
puede comprobar en 1780 cuando se producen pagos por valor de casi 100.000 reales para cubrir fundamentalmente nóminas de la Subcolecturía (en torno a un $70 \%$ del total) cuando las entregas de 1779 no llegaron a los 10.000 y en la documentación no hay referencia expresa a los salarios de estos oficiales desde 1777. Salarios que, por otra parte, tampoco fueron regulares ni en forma ni en cantidad. En ocasiones, algún oficial cobraba dos veces en el mismo año como el fiscal Sebastián Herrero que tomó $2.333,11$ reales y $10.666,22$ reales en el mismo ejercicio. ${ }^{126}$ Otras veces, las nóminas fueron alteradas por gratificaciones e incentivos como los 12.500 reales librados al subcolector Ignacio Ceballos «por pasadas y futuras tareas» en $1780 . .^{127}$ Pablo Antón observa que los pagos a los oficiales de la Subcolecturía gaditana se realizaron al finalizar la gestión del proceso del obispo Tomás del Valle, producto del prorrateo entre el espolio y la vacante y de la negociación entre Cádiz y Madrid que finalmente determinó unas cantidades muy bajas. No obstante, esta situación no fue óbice para que el colector general recibiera una de las mejores alhajas del pontifical del prelado dominico, regalo prescrito por Real Orden de 15 de mayo de 1756 del que no tenemos constancia para Sevilla. ${ }^{128}$

En 1785, además de las características nóminas de la institución, los pagos se engordaron algo más con respecto a 1781-1784 (hasta cerca de los 50.000 reales) debido a unas quiebras por renta de pan de 1773 y al maestro alarife José Álvarez por unas obras en la hacienda de la Fuensanta. ${ }^{129}$

En definitiva, podemos decir que los mayores pagos se realizaron por seis conceptos fundamentales: subsidio y excusado, nóminas de diferente tipo, censos atrasados, pensiones de la mitra, acreedores probados al espolio y obras. ${ }^{130}$ En todas estas categorías hubo libramientos superiores a los 25.000 reales. La partida más suculenta: los 600.000 reales que se libraron de una vez al infante Luis Jaime de Borbón, arzobispo dimisionario de Sevilla, por su pensión sobre las rentas de la mitra en $1775 .{ }^{131}$ Realmente, las pensiones fueron una de las grandes vías de escape del caudal del espolio y la vacante. Registradas como tal en la documentación y con unas fechas extremas que van de 1775 a 1778 se contabilizan a su favor $1.816 .800,31$ reales, algo menos de la mitad del capital librado (45\%) durante toda la administración del producto. Además del Borbón, otros beneficiarios de estas pensiones perpetuas o renovables, que cargaba el monarca al momento de presentar la mitra y que el prelado debía aceptar, fueron el obispo auxiliar, Agustín Ayestarán, la capilla real de la catedral, los hospitales Real, de San Cosme y San Damián, del Pozo Santo dentro del arzobispado de Sevilla y la iglesia asturiana de Covadonga, la colegial cordobesa de San Hipólito, los conventos de la Encarnación y de las Descalzas Reales de Madrid, la Orden de Carlos III, el hospital de la Marina de Cádiz, de fuera de la jurisdicción hispalense, además de otros particulares.

\footnotetext{
126 Ibídem, legajo no 831 y 840.

127 Ibídem, legajo no 831.

128 Antón Solé 1985: 146.

129 AGAS, Administración, Espolios y Vacantes, legajo no 831.

130 Ibídem, legajo $n=840$.

131 Ibídem, legajo no 831.
}

Ciertos censos atrasados con sus réditos ocuparon otra parte importante de las salidas de caudal durante la administración. En concreto, contabilizamos algo más de un millón de reales ( $28 \%$ del total) con destino a varias rentas eclesiásticas de Carmona, Jerez o Utrera y diferentes obras pías de Écija que el arzobispo Solís tomó sobre las rentas de su hacienda de la Fuensanta o San Cristóbal en 1769. ${ }^{132}$

Aunque no fue un desembolso importante, no queremos dejar pasar los gastos que generaron las exequias del arzobispo Solís en la capital del arzobispado. No incluimos aquí la liquidación que se produjo por el entierro del cardenal en Roma porque la embajada se encargó de liquidar todo devolviendo un caudal libre de adeudos, además de aquellos bienes que inventarió. Por tanto, esta tramitación quedó fuera de la competencia de la Subcolecturía de Sevilla. Según la documentación recogida por los subcolectores, los gastos de la muerte del prelado ascendieron a $26.603,28$ reales en concepto de funeral, testamentaría y acto de recibimiento y colocación de su corazón en el Monasterio de Santa Rosalía. No obstante, el coste del funeral $(21.525,12)$ ofrecido por la institución contrasta con el dato que se nos facilita desde el Fondo Histórico General del Archivo Capitular y que, probablemente, realizara la diputación de ceremonias de la catedral $(25.393,39)$ y que desglosa con mucho más detalle: coste de la cera $(21.818,24)$, derechos parroquiales del funeral que se celebró en la iglesia del Sagrario $(1.425,08)$, ofrenda de pan y vino (1.400) y sermón de cuerpo presente (750). ${ }^{133}$

Frente a los cerca de cuatro millones de reales empleados en pagar obligaciones contra el espolio y la vacante, sólo algo menos de millón $(984.807,23)$ se destinó a tratar aquellos fines originarios de la regalía siendo las dotes matrimoniales el concepto que más numerario acaparó (un $37 \%$ del total). ${ }^{134}$ Aunque no hayamos encontrado rastro entre la documentación, las peticiones que debieron llegar a la Subcolecturía influyeron en la determinación de las cantidades libradas. ${ }^{135}$ Principalmente, éstas se realizaron entre el año 1779, cuando debía estar recaudado la mayor parte de los frutos del espolio y la vacante, y los primeros años de la década de los ochenta, aunque no faltan algunas partidas de los últimos años e incluso de 1791. Además de las dotes a casaderas, hemos distinguido otras seis categorías o grupos y, como en casos anteriores, difícilmente el escribano separa las partidas del espolio y la vacante. ${ }^{136}$

Hacia las instituciones religiosas o asistenciales se derivaron 413.322 reales. Los mayores libramientos se efectuaron a las fábricas de las parroquias: 176.549 reales en 108 libramientos, mayoritariamente de pueblos del arzobispado y, en concreto, localizados por el Aljarafe, el área metropolitana de Sevilla y la sierra onubense. Las cantidades son muy dispares y se sitúan entre los 5.000 reales que recibió la iglesia de Santa Lucía de la capital, de

132 AGAS, Justicia, Espolios y Vacantes, legajo 3.041.

133 ACS, Fondo Histórico General, legajo 11.274/3, exp. 72.

134 Esta preferencia también se observó en el caso de Cádiz. Antón Solé 1985: 169.

135 Mercedes Calvo tampoco encuentra testimonios sobre las necesidades de la diócesis de Canarias (Calvo Cruz 2000: 437). Sin embargo, para el caso gaditano, Antón Solé cuenta con un informe general elaborado por el subcolector que aborda el estado de los diferentes pueblos de la diócesis de Cádiz (Antón Solé 1985: 154-167).

136 AGAS, Administración, Espolios y Vacantes, legajo nㅇ 840. 
gran pobreza, y la parroquial de Brenes, pueblo de la vega del Guadalquivir, que sólo recibió 1.000. Las limosnas a órdenes religiosas oscilaron entre los 25.550 reales concedidos a comunidades masculinas y el doble que recibieron las femeninas por razones obvias de pobreza y clausura. Las dos terceras partes de las casas masculinas representadas fueron de la familia franciscana (observantes, mendicantes, capuchinos, terciarios) estando atendidas casi por mitad las de la capital y las del resto de la archidiócesis. El $60 \%$ de las solicitudes recibieron 1.000 reales siendo una excepción los 6.000 que recibieran los oratorianos de San Felipe Neri. En cuanto a la rama femenina, cerca del $70 \%$ de las peticiones cursadas fueron resueltas con 1.300 reales. En este caso, la casa más favorecida fue la de las Capuchinas de El Puerto de Santa María que, además de recibir los donativos más sustanciosos, lo hicieron por partida doble: 6.000 y 5.000 reales en el mismo año de 1779 . Las instituciones de caridad percibieron 161.223 reales de los que principalmente se benefició la casa de niñas huérfanas de Marchena con 20.000. ${ }^{137}$

A los particulares se les otorgó el 58\% del capital que no fue a parar a las instituciones. Entre los donativos para ingresar en un convento y para contraer matrimonio se encuentra el $90 \%$ de lo librado y sólo el $10 \%$ restante se destinó a cubrir las necesidades de algunos particulares. Nos referimos, por ejemplo, al socorro de 12.000 reales que recibieron varias familias pobres de marineros o los más de 27.000 con los que se pretendió paliar la miseria de jornaleros de diecinueve lugares del arzobispado. Como ya hemos comentado, las dotes para tomar estado fueron el destino más solicitado de las ayudas. Según preveía la ley... «(El subcolector) también averiguará, quanto sea posible, las pobres doncellas que haya en disposición de tomar estado, y que por falta de competente dote no lo han conseguido, ni verosímilmente lo conseguirán, si no se les socorre...». ${ }^{138}$ En Cádiz, como en Sevilla, se dio preferencia a las diocesanas. ${ }^{139}$

Entre 1779 y 1791 se dotaron cerca de doscientas mujeres casaderas con una cantidad que osciló para la mayoría entre los 1.100 y 2.200 reales. Fuera de esa cifra se situaron, una de 1.000 reales, una quincena de 3.300 reales y una, muy jugosa, de 6.600 reales que correspondió a una tal Josefa Benítez de la localidad de Morón. No fue, sin embargo, Morón el pueblo que más donativos recibió por este concepto. Los lugares de Albaida del Aljarafe, El Garrobo, Mairena del Aljarafe, Rota, Los Palacios, El Pedroso o las vicarías de Carmona y Niebla fueron las que se atendieron en mayor número de ocasiones. En cuanto a las monjas, las dotes más altas (6.600 reales) recayeron en Catalina Pacheco y María del Carmen Sire para ingresar en el convento sevillano de las Dueñas y en las clarisas de Tordesillas, respectivamente. Debemos destacar que éste es el único libramiento extradiocesano que hemos encontrado. El $65 \%$ de estas ayudas vacilaron entre los 2.200 y los 3.300 reales. ${ }^{140}$

\footnotetext{
137 Ídem.

138 Novísima Recopilación... 1805: ley II, título XIII, libro II.

139 Antón Solé 1985: 171.

140 AGAS, Administración, Espolios y Vacantes, legajo no 840.
}

\section{CONCLUSIONES}

Tras varios siglos de pleitos con Roma, la Corona finalmente obtuvo o restauró, según el pensamiento regalista, el derecho de administrar los espolios y vacantes de las principales dignidades eclesiásticas del Estado. En Sevilla, hemos tenido la oportunidad de analizar el desarrollo de su gestión a través del caso concreto del arzobispo Francisco Solís, primer prelado fallecido en la Sede tras el Concordato de 1753 , y hacer varias consideraciones.

En primer lugar, hemos comprobado que la Colecturía General de Espolios y Vacantes, creada ex profeso para esta gestión, mantuvo un clima de cordialidad institucional con otras administraciones, véase la Embajada de España en Roma o la propia Iglesia. No en vano, ambas procuraban el buen desarrollo de la maquinaria del Estado en la medida que sus componentes eran propuestos en última instancia por el monarca gracias, en este último caso, al derecho de patronato universal. Además, buena parte de los miembros de la Subcolecturía y el colector por imperativo legal eran dignidades eclesiásticas. ${ }^{141}$ Sin embargo, según Calvo, la Colecturía General tuvo problemas de competencias tanto con el Ministerio de Gracia y Justicia como con las Audiencias por interferencia en sus caudales. ${ }^{142}$ Igualmente, desconocemos las comunicaciones entabladas entre la institución central y la subalterna de Sevilla.

Continuando con la labor emprendida por estas organizaciones, en general, podemos decir que se atuvieron a la legalidad e intentaron cumplirla. Así se observa en distintos momentos como la ocupación de las dependencias arzobispales al proclamarse la muerte del prelado o la rápida ejecución de procesos como la almoneda en la capital hispalense. No podemos concluir lo mismo respecto a la elaboración del inventario de bienes en Sevilla o el registro de la biblioteca, quizás perdidos pues no se explica la escasa entidad de la librería arzobispal ni que se pusiera a la venta cuando existió una normativa al respecto que obligaba a su reserva. Por otra parte, no podemos dejar de reparar en la falta de organización de los oficiales de Subcolecturía que, lejos de los condicionantes impuestos por este caso concreto, mezclaron partidas de diferentes ramos e incluso los espolios y vacantes de dos arzobispos. Esta improvisación podría justificarse en la inexperiencia de una institución que no contaba con más de dos décadas de vida, aunque los estudios de Calvo Cruz revelan de manera general para todo el periodo efectivo de la Colecturía (1753-1851): ineficacia en la dirección y control de las subcolecturías, escaso control de los subcolectores, irregularidad en el cumplimiento de la normativa contable y ocultación de datos. ${ }^{143}$

Sin ir más lejos, en Sevilla observamos cierta arbitrariedad incluso en el pago de las mismas nóminas que no sólo eran irregulares en el fondo sino también en la forma. $\mathrm{Y}, \mathrm{a}$ falta de recibos o instancias que lo atestigüen, estas veleidades también pudieron presidir otras partes del proceso del espolio y la vacante. Para los historiadores, estas circuns-

141 No ocurrió así durante el espolio y vacante del obispo gaditano Tomás del Valle. Según Antón, la relación del subcolector Pedro Sánchez fue tirante con el cabildo durante los primeros meses de su gestión por su celo excesivo (Antón Solé 1985: 111).

142 Calvo Cruz 2000: 454.

143 Ibídem: 460 
tancias son enojosas y pueden restar veracidad al relato. Sin ir más lejos, por las divisiones que realiza, el inventario desarrollado en Roma hace pensar a primera vista que el arzobispo Solís era ajeno al mundo artístico si no reparásemos que, entre las deudas liquidadas, hubo alguna pieza de cierto interés. En cualquier caso, una buena documentación de los espolios y vacantes no deja de ser una fuente privilegiada de información económica y asistencial de la diócesis así como de la dirección del gasto de estas dignidades de la Iglesia y del cumplimiento de los fines de esta regalía: el auxilio de los más necesitados.

Según el caso particular de Sevilla, podemos decir que pocas ayudas se libraron en comparación con los numerosos gastos que se detrajeron de la administración de lo recaudado (cerca del $80 \%$ ). ${ }^{144}$ En efecto, durante el proceso de colectación se ingresaron en las arcas de la Subcolecturía en torno a cinco millones de reales procedentes de diezmos, fundamentalmente, pero también de ventas por patrimonio y deudas saldadas en efectivo además de 60.000 fanegas de grano de las que no conocemos liquidación. Una cantidad apreciable aunque no hemos incorporado aquellas deudas patentes al espolio por desconocerse en muchos casos no sólo la reintegración sino la cuantía. De forma simultánea, el capital adquirido se fue administrando dejando en concepto de acreedores, impuestos, pensionistas o nóminas casi cuatro millones de reales. Por tanto, aunque aproximados, con estos datos parece evidente que sólo hubo de quedar algo más de un millón de reales para cubrir aquellas necesidades de los diocesanos. Millón que se acerca a los $984.807,23$ reales que hemos estimado en libranzas de la Subcolecturía y que tuvo en las doncellas casaderas su principal foco de atención (37\% del total librado). Según el clásico estudio de Christian Hermann, este destino fue general entre los espolios españoles de los años 17751782 rozando el $24 \%$ de las libranzas totales y, en años anteriores, incluso superó el 30\%. Esta categoría sólo fue desbancada momentáneamente por las limosnas a fábricas y comunidades religiosas, sobre todo en los primeros años de la Colecturía General, las instituciones asistenciales y en la franja que transcurre entre 1785-1798 cuando hospitales, hospicios, pobres de solemnidad y un concepto no contemplado antes como la industria y los trabajos públicos agrupó en torno a sí el 76,9\% de las liquidaciones. ${ }^{145}$

Junto a las pensiones impuestas por el monarca que fueron la principal salida de la administración, Carlos III intervino en varias ocasiones para contribuir, por ejemplo, al Fondo de Bulas, años antes de que se finalizara la recaudación y que se llevaran a término las políticas asistenciales que prescribió la regalía. Luego, una prioridad del monarca fue la de extinguir los vales reales con estos frutos. ${ }^{146}$ Como vemos, a falta de estudios que amplíen la materia, la maltrecha hacienda borbónica no permitió que madurasen los esplendores de la administración del nuevo derecho ni tampoco que se cubrieran sus auténticos fines.

144 El caso estudiado de Cádiz, simultáneo al del arzobispo sevillano, obtuvo en la exacción 1.390.541 reales pudiendo librar únicamente 651.127 reales. El 53,17\% del producto restante se encaminó a saldar deudas, cargas y responsabilidades de la mitra (Antón Solé 1985: 184).

145 Hermann 1988: 180-188.

146 Calvo Cruz 2000: 464.

\section{BiBLIOGRAFÍA}

Alonso Morgado, J. 1906. Prelados sevillanos o episcopologio de la Santa Iglesia Metropolitana y Patriarcal de Sevilla. Sevilla: Tipografía de Agapito López.

Alonso Perujo, N. y Pérez Angulo, J. 1886. Diccionario de Ciencias Eclesiásticas. Barcelona.

Álvarez Baena, J. A. 1790. Hijos de Madrid, ilustres en santidad, armas, ciencias y artes: tomo II. Madrid: Oficina de Benito Cano.

Álvarez Santaló, L. C. 1997. «Las esquinas aritméticas en la propiedad del libro en la Sevilla ilustrada». Bulletin hispanique 99 (1): 99-134.

Álvarez Santaló, L. C. y García-Baquero, A. 1980. «La nobleza titulada en Sevilla, 1700-1834». Historia, Instituciones y Documentos 7: 125-168.

Amores Martínez, F. 2000. "Las empresas artísticas del arzobispo ilustrado Alonso Llanes y Argüelles (1783-1795)». Laboratorio de Arte 13: 173-192.

Andueza Unanua, P. 2009. «Joyas personales, alhajas para la casa y libros para el alma: el inventario de bienes de los duques de Granada de Ega en el siglo XVIII». Príncipe de Viana 247: 271-301.

Antón Solé, P. 1974. «Los fondos documentales de los espolios y vacantes de las mitras españolas como fuente para la historia eclesiástica de España», en En torno a Pemán: 385-399. Cádiz: Diputación de Cádiz.

Antón Solé, P. 1985. Situación económica y asistencia social de la diócesis de Cádiz en la segunda mitad del siglo XVIII. Cádiz: Caja de Ahorros y Monte de Piedad de Cádiz.

Ballesteros Robles, L. 1912. Diccionario biográfico matritense. Madrid: Imprenta Municipal.

Barrio Gozalo, M. 1982. Estudio socioeconómico de la Iglesia de Segovia en el siglo xVIII. Segovia: Caja de Ahorros y Monte de Piedad de Segovia.

Barrio Gozalo, M. 2010. El clero en la España Moderna. Córdoba/ Madrid: Cajasur/CSIC.

Belmonte Mas, F. J. 2000. «El cónclave de 1769 en la correspondencia diplomática». Revista de Historia Moderna: Anales de la Universidad de Alicante 18: 67-84.

Benito Golmayo, P. 1878. Instituciones del Derecho Canónico. Madrid: Librería de Gabriel Sánchez.

Calvo Cruz, M. 2000. La contabilidad de espolios y vacantes. Las Palmas de Gran Canaria: Universidad de las Palmas.

Campos Harriet, F. 1995. "El expolio en el derecho indiano», en Memoria del $X$ Congreso del Instituto Internacional de Historia del Derecho Indiano: 199-208. México: Universidad Nacional Autónoma de México.

Candau Chacón, M. L. 1994. El clero rural de Sevilla en el siglo xVIII. Sevilla: Caja Rural de Sevilla.

Castellanos de Losada, B. S. (ed.) 1867. Bibliografía eclesiástica completa: tomo XXVII. Madrid: Imprenta de Alejandro Gómez Fuentenebro.

Cortés Peña, A.L. 1989. La política religiosa de Carlos III. Granada: Universidad de Granada.

De la Fuente, V. 1873-1875. Historia eclesiástica de España: tomo VI. Madrid: Compañía de impresores y libreros del Reino.

De la Hera, A. 1963. El regalismo borbónico en su proyección indiana. Madrid: Rialp.

Domínguez Ortiz, A. 1944. "El reino de Sevilla a fines del siglo XVIII según las relaciones enviadas a don Tomás López». Archivo Hispalense 6-8: 229-259.

Febres, L. 2009. "La devoción mariana presente en el expolio del obispo Mariano Martí. Provincia de Venezuela de 1792». Boletín de la Academia Nacional de Historia 92 (366): 43-85.

Ferraris, L. y Soler, A. 1788. Prompta Bibliotheca...: tomo VII. Madrid: Tipografía de Miguel Escribano.

García Fernández, M. 2008. «Percepciones de la apariencia castellana dentro de España y Roma: imagen, cultura material y estilos de vida a finales del Antiguo Régimen ». Cuadernos Dieciochistas 9: 119-151.

Gil-Bermejo, J. 1970. «El espolio de un Obispo (México, 1708)». Anuario de Estudios Americanos 27. 
Gómez Bravo, J. 1778. Catálogo de los obispos de Córdoba y breve noticia histórica de su iglesia catedral y obispado: tomo II. Córdoba: Imprenta de Juan Rodríguez.

Gómez Salazar, F. 1877. Instituciones de Derecho Canónico. Madrid: Imprenta de Alejandro Gómez Fuentenebro.

Guitarte Izquierdo, V. 1992. Episcopologio español (1700-1867). Castellón de la Plana: Ayuntamiento de Castellón.

Hermann, C. 1988. L'Eglise d'Espagne sous le patronage royal (14761834). Madrid: Bibliotheque de la Casa de Velázquez.

Herrera García, A. 1980. El Aljarafe sevillano en el Antiguo Régimen. Sevilla: Diputación de Sevilla.

Ibáñez Rodríguez, S. 1994. «El diezmo en la Rioja (XVI-XVIII)». Brocar 18: $189-222$

Ladero Fernández, C. L. 2010. «Semblanza de un arzobispo de Sevilla: Francisco Solís Folch de Cardona (1755-1775)». Anuario de Historia de la Iglesia Andaluza 3: 117-122.

Ladero Fernández, C. L. 2011. "La archidiócesis de Sevilla a fines del Antiguo Régimen: apuntes sobre su organización económica y pastoral». Anuario de Historia de la Iglesia Andaluza 4: 143-198.

Ladero Quesada, M. A. y González Jiménez, M. 1978. Diezmo eclesiás tico y producción de cereales en el reino de Sevilla (1408-1503). Sevilla: Universidad de Sevilla.

López Martínez, A. L. 2002. Ganaderías de lidia y ganaderos: historia y economía de los toros de lidia en España. Sevilla: Universidad de Sevilla.

Marién y Arróspide, A. 1789. Tratado general de monedas, pesas, y medidas y cambios de todas las naciones, reducidas a las que se usan en España. Madrid: Imprenta de Benito Cano.

Martín Riego, M. 1990. Diezmos eclesiásticos, rentas y gastos de la mesa arzobispal hispalense (1750-1800). Sevilla: Caja Rural de Sevilla.

Martín Riego, M. 1992. "Sevilla de las Luces», en C. Ros Carballar (ed.), Historia de la Iglesia de Sevilla. Sevilla: Castillejo.

Martín Riego, M. 2002a. "La Sevilla de las luces (1700-1800)», en J. Sánchez Herrero (ed.), Historia de las diócesis españolas: Sevilla, Huelva, Jerez, Cádiz y Ceuta. Madrid: Biblioteca de Autores Cristianos/Cajasur.

Martín Riego, M. 2002b. "Limosna y caridad en los arzobispos de Sevilla (1755-1795)». Isidorianum 21-22: 415-476.

Melón Jiménez, M. A. 1987. «Los diezmos de la diócesis de Coria (1566-1733)». Studia Histórica 5: 177-190.
Melón Jiménez, M. A. 1998. "Los diezmos de los ganados trashumante. Un estudio sobre sus peculiaridades en Extremadura». Studia Histórica 18: 321-352.

Molí Frigola, M. 1990. "Sevilla en Roma. Los viajes del cardenal Francisco Solís». Archivo Hispalense 224: 67-86.

Novísima Recopilación de las leyes de España... 1805. Madrid, [s.n.].

Olivares Terol, M. J. 2001. «El expolio de Gonzalo Arias Gallego, obispo de Cartagena-Murcia (1565-1575)». Carthaginensia 32: 413-434.

Porres Benavides, J. y Sánchez López, M. 2008. «Un original desconocido (o perdido) y tres versiones del retrato del cardenal Solís». Archivo Español de Arte 323: 315-322.

Quintana Andrés, P. 2006. "Actitudes del alto clero canario ante la muerte: preeminencia, ostentación social y conflictividad durante la Edad Moderna». El museo canario 61: 118-216.

Ritzler, R. y Sefrin, P. 1958. Hierarchia catholica...: tomo VI. Patavii.

Ros Carballar, C. 1986. Los arzobispos de Sevilla. Luces y sombras en la sede hispalense. Granada: Anel.

Rubio Merino, P. 1987. Archivo de la Santa Metropolitana y Patriarcal Iglesia Catedral de Sevilla. Inventario General. Madrid: Fundación Ramón Areces.

Sanz de la Higuera, F. 2002. "Familia, hogar y vivienda en Burgos a mediados del siglo XVIII. Entre cuatro paredes compartiendo armarios, camas, mesas y manteles». Investigaciones Históricas 22: $165-212$.

Suplemento al Diccionario razonado de legislación y jurisprudencia de Joaquín Escriche 1847. Madrid: La llustración.

Tejada Ramiro, J. 1859-1863. Colección de Cánones y de todos los Concilios de la Iglesia de España y América: tomo VIII. Madrid: Imprenta de Pedro Montero.

Vigo Trasancos, A. 1993. «El arzobispo compostelano Bartolomé Rajoy y Losada (1751-1772). Gusto artístico y mecenazgo arquitectónico». Norba Arte 13: 115-140.

Yzquierdo Perrín, R. 2006-2007. «El mecenazgo del arzobispo compostelano Don Lope de Mendoza en Santiago y Padrón». Abrente: Boletín de la Real Academia Gallega de Bellas Artes de Nuestra Señora del Rosario 38-39: 117-172.

Zunzunegui Aramburu, J. 1965. "La percepción de los espolios del Obispo de Tortosa D. Jaime Cyon (1348-1351)». Anthologica Annua 13: 361-390. 